\title{
Oil-collecting bee-flower interaction network: do bee size and anther type influence the use of pollen sources?
}

\author{
Laíce S. Rabelo ${ }^{1}$, Alice M. G. F. Vilhena ${ }^{1}$, Esther M. A. F. Bastos ${ }^{2}$, \\ Cândida M. L. Aguiar ${ }^{3}$, Solange Cristina Augusto ${ }^{1}$ \\ ${ }^{1}$ Instituto de Biologia, Universidade Federal de Uberlândia, Rua Ceará, Campus Umuarama, s/n. Caixa Postal 593, \\ Uberlândia, Minas Gerais CEP 38400-902, Brazil \\ ${ }^{2}$ Diretoria de Pesquisa e Desenvolvimento, Laboratório de Recursos Vegetais e Opoterápicos, Fundação Ezequiel Dias, \\ Belo Horizonte, Brazil \\ ${ }^{3}$ Departamento de Ciências Biológicas, Universidade Estadual de Feira de Santana, Feira de Santana, Brazil
}

Received 26 June 2014 - Revised 7 November 2014 - Accepted 24 November 2014

\begin{abstract}
Pollination is an ecosystem service sustained by a differentiated use of resources among sympatric species. The bee size can influence the similarity in the use of resources, and poricidal anthers limit the access to pollen. Therefore, we evaluated the influence of body size and the anther type of pollen sources in Centridini-flower interaction network. We expected that the low niche overlap, promoted by these morphological parameters, would result in the formation of subgroups and lead to greater network resilience. We studied 15 bee species $(n=73$ females) and identified their pollen sources. The bee size and anther type influenced the formation of subgroups in the community, and the larger bees used a higher proportion of flowers with poricidal anthers. Only the anther type influenced the robustness of the network. We conclude that the parameters analyzed influence both the use of resources by oil-collecting bees and their food niche breadth.
\end{abstract}

pollen analysis / robustness / ecosystem services / solitary bees / trophic niche

\section{INTRODUCTION}

Organisms interact with each other in search of resources and the ecosystem services, such as pollination, depend on the maintenance of these interactions. The maintenance of pollination services is associated with the differentiated use of resources among sympatric species due to morphological and behavioral differences (Begon et al. 2006). In beeplant systems, the body size influences the foraging distance of bees (Greenleaf et al. 2007) and the similarity in the use of resources, which seems to be greater between species with similar body size

Corresponding author: S. Augusto, scaugusto@umuarama.ufu.br

Manuscript editor: Klaus Hartfelder
(Cortopassi-Laurino et al. 2003; Nogueira-Ferreira and Augusto 2007). In plants, the presence of poricidal anthers limits the access of bees to pollen, because the release of the grains results from the energy produced by the vibration of anthers at the proper frequency (Buchmann 1978). Bees are able to vibrate at different frequencies according to their body size (Buchmann 1978; Harder and Barclay 1994). Larger bees present a lower buzzing frequency during pollen collection in poricidal anthers than smaller species, which is likely to lead to lower energy consumption (Burkart et al. 2011).

The recognition of the influence of these characteristics in the community structure can be performed using analyses of pollen and interaction network. The first tool allows identifying food sources used by bees (Jones and Jones 2001). The second tool is used for the construction of a visual model of the community structure and the 
identification of network properties, such as robustness and niche overlap (Jordano et al. 2003; Memmott et al. 2004; Lewinsohn et al. 2006; Dormann and Gruber 2012). The robustness represents the tolerance of the networks to species extinctions (Memmott et al. 2004) and can be affected by generalization of the species or number of links (Memmott et al. 2004; Staniczenko et al. 2010), connectance of the network (Dunne et al. 2002), and habitat loss (Evans et al. 2013).

The niche overlap represents the resource sharing among different species in a community (Begon et al. 2006). In bee-plant systems, characteristics such as the tongue length (Goulson and Darvill 2004), level of specialization of bees and flower abundance (Aguiar et al. 2013), and temporal aspects of resource availability (Carvalho et al. 2013; Santos et al. 2013) can influence the niche overlap among the species.

Centridini bees are important pollinators of cultivated species (Freitas and Paxton 1998; Vilhena et al. 2012; Yamamoto et al. 2012; Oliveira et al. 2013). The bees of this group are specialized in collecting floral oils, especially from Malpighiaceae species, which can be used as bait plants (Alves-dos-Santos et al. 2007; Ribeiro et al. 2008; Vilhena et al. 2012; Oliveira et al. 2013). Centridini bees present variation in the body size among the species, i.e., bees of medium-large body length $(\geq 1.2 \mathrm{~cm})$ and small bees $(\leq 1.2 \mathrm{~cm})$ (sensu Frankie et al. 1983), and can vibrate at different frequencies according to their body size (Buchmann 1978).

Thus, the chief goal of this study was to evaluate if the parameters, body size of the Centridini species and the anther type presented by their pollen sources, influence in the structure of this bee-plant community. We expect that these parameters influence the use of pollen sources to reduce the niche overlap. The lower niche overlap would result in the formation of subgroups and, therefore, lead to a greater resilience of the network to the removal of species and to the maintenance of the pollination services. The presence of subgroups in the community may hinder the cascade effect of extinction in plant-pollinator networks (Bosch et al. 2009).

To evaluate these possible effects, we identified the pollen sources used by Centridini bees and their food niche breadth. We verified whether there were subgroups in the community, considering the anther type of flowers and body size of bees. We also calculated the robustness of the community to the systematic removal of bee species in descending order of body size and according to the anther type.

\section{MATERIAL AND METHODS}

\subsection{Study area}

The study was conducted at the Experimental Station of Água Limpa ( $19^{\circ} 05^{\prime} 48^{\prime \prime} \mathrm{S} / 48^{\circ} 21^{\prime} 05^{\prime \prime} \mathrm{W}$ ), belonging to the Federal University of Uberlândia, located in Uberlândia, Minas Gerais State, Brazil. The station comprises $1,040,000 \mathrm{~m}^{2}$ of woody savanna and $1,947,200 \mathrm{~m}^{2}$ of pastures, crops, and orchards (Neto 2008). The climate is characterized by two distinct seasons, one hot and wet (from October to March) and other cold and dry (from April to September) (Rosa et al. 1991).

\subsection{Sampling of Centridini bees}

The Centridini bees were collected during their visits to flower of West Indian cherry or acerola (Malpighia emarginata DC) crop. Among the cultivated species in the study area, there were approximately $11,000 \mathrm{~m}^{2}$ of West Indian cherry trees. This species is selfincompatible and dependent upon pollination made mainly by Centridini bee species (Freitas et al. 1999; Vilhena et al. 2012; Oliveira et al. 2013). In a long-term study about West Indian cherry pollination, Vilhena et al. (2012) collected 23 species of Centridini bees collecting mainly oil as floral resource.

Most of species of Centridini bees are active during the wet season, the flowering period of $M$. emarginata and other Malpighiaceae species (Gaglinone 2003; Vilhena et al. 2012). To identify the pollen sources used by them and calculate the niche breadth, we collected females with pollen loads on their scopa while they were visiting West Indian cherry flowers. The females were collected in October/November and January/ February (one sample/month) from 2004 to 2011, totaling 24 sampling days and $120 \mathrm{~h}$ of observation. The bees were sampled between 9:00 A.M. and 14:00 P.M. One researcher carried out the collections walking along the inter-rows. Each shrub that presented inflorescences 
was observed for about $5 \mathrm{~min}$. Because individuals of this tribe visit West Indian cherry trees preferably to collect oil (Vilhena and Augusto 2007), and there is a variation in the frequency of visits of these pollinators over the years (Vilhena et al. 2012), we needed to realize a long-term study (2004-2011) to obtained samples of pollen loads from most species of floral visitors. We considered the pollen load of each female as a sample.

Females were collected using entomological nets. They were placed individually in plastic bottles and taken to the laboratory, where they were frozen. Only the pollen grains present in their scopas were removed, to prevent contamination by grains present in the bee's abdomen. The samples were stored in $2 \mathrm{~mL} 70 \%$ ethanol and then acetolized (Erdtman 1960). For each individual, we prepared three slides that were deposited in the collection of the Laboratory of Ecology and Behavior of Bees, Federal University of Uberlândia, Brazil.

We analyzed 73 samples from 15 bee species, and the number of sample per species ranged from two to eight. Due to the difference in the number of samples among the bee species, we verified the quality of pollen sampling effort constructing extrapolation curves using EstimateS (Colwell 2013). The extrapolation analysis is able to estimate the asymptotic number of species ("target richness"), including species not documented by the reference sample (Colwell 2013). Based on the fact that the estimation is adequate, it is expected that the higher percentage of pollen types observed best is the sampling.

The niche breadth was calculated using the Shannon-Wiener index $\left(H^{\prime}\right)$, as proposed by Camillo and Garófalo (1989). We also verified whether the number of samples influences the niche breadth and the percentage of the expected number of pollen types collected, using Spearman correlation tests (Zar 2010).

Pollen grains were identified from morphological characteristics by comparing literature (SalgadoLabouriau 1973; Roubik and Moreno 1991), a database of pollen images (Bastos et al. 2008), and by comparison with reference material of the study area. This study used the taxonomic classification proposed by Angiosperm Phylogeny Group II (Souza and Lorenzi 2005). The pollen grains that presented similar morphology were grouped into pollen types according to which were previously proposed in the literature (Vilhena et al. 2012; Rabelo et al. 2012).
After the identification of the plants used as pollen sources by Centridini bees, we performed quantitative analysis dividing the coverslip into four quadrants. There were counted approximately 100 pollen grains in each quadrant, and among those with fewer than 100 grains, we counted all grains, totaling 1,200 grains per sample (Vilhena et al. 2012). For this analysis, we used $200 \times$ increase of magnification. Pollen types with proportion lower than $3 \%$ in each sample were discarded, as they were considered contaminants or only sources of oil or nectar.

\subsection{Body size of bees and use of pollen sources according to anther type}

The body size of bees was determined from measurements of mean of intertegular span (mean in millimeters \pm SD) (Cane 1987) measured with the aid of a caliper. For each species, we measured four individuals (total=60 females).

We used the Non-metric Multidimensional Scale (NMDS) analysis to explore how Centridini bee species could be grouped in a multidimensional space based on the dissimilarity in the use of pollen sources according to anther type (Quinn and Keough 2002). For this analysis, the pollen sources were separated into three categories [Malpighiaceae, non-Malpighiaceae/nonporicidal (NMNP), and poricidals]. The Malpighiaceae and NMNP categories comprised species with nonporicidal anthers but were separated due the close relationship between oil-collecting bees and oil-plants. The category poricidal was composed of species that present flowers with poricidal anthers. The analysis was performed in R, using the Vegan package. The anther type and the flower's resources of each plant were determined according to literature (see Anderson 1979; Buchmann 1983; Oliveira et al. 1987; Oliveira and Gibbs 1994; Kill et al. 2000; Carvalho and Oliveira 2003; Fracasso and Sazima 2004; Pereira and Barbosa 2004; Andena et al. 2005; Ragusa-Netto 2005; Souza and Lorenzi 2005; Del Lama and Peruquetti 2006; Filho et al. 2007; Pool 2009).

To verify the influence of body size on the ordination of the species in the multidimensional space, we used a Spearman correlation between the intertegular span of all bee species and the scores generated in NMDS for the first axes (which represents all the pollen sources 
used by the bees and the major variance of data) (Zar 2010).

\subsection{Robustness and niche overlap}

The network between oil-collecting bees and their pollen sources was constructed based on an adjacency matrix, in which bee species were arranged in rows and pollen types in columns. The matrix cells were filled with the number of pollen grains counted for each bee species.

To verify the effect of body size of the bees and anther type of flowers (Malpighiaceae, NMNP, and poricidals), the robustness of the structure was calculated based on systematic and random removals. The exclusion criterion was the removal of bee species based on their body size (first the largest, then the smallest one) and anther type (first Malpighiaceae, then poricidals and NMNP).

The value of robustness varies between 0 and 1 . Values of robustness near 0 indicate a fragile system in which the extinction of a small number of species can lead to a great number of co-extinctions, due to the loss of all interactions. On the other hand, robustness near 1 represents a resilient system, in which the removal of a large number of species results in a small number of coextinctions (see Dormann and Gruber 2012). This parameter was calculated using the Bipartite-R package for second.extinct and robustness functions. To investigate whether the robustness observed was significantly different from the random values, we compared the observed values with the mean value obtained from null models $(n=1,000)$ using the one-sample $t$ test (Zar 2010). The null models were constructed using the nullmodel function and the method 1, from the Bipartite-R package (Dormann and Gruber 2012).

We used the function networklevel from the Bipartite-R package to calculate the niche overlap (mean $\pm \mathrm{SEM}$ ), separately for bee species and pollen types. The niche overlap represents the mean pattern of similarity in interactions among bees or pollen types, based on Horn's index. Values of this parameter near 0 indicate low sharing of resources, and 1 indicates perfect niche overlap (see Dormann and Gruber 2012).

Considering that the greater density of $M$. emarginata compared to the native species may cause a bias in the analyses of robustness and niche overlap, we repeated these analyses excluding this bait plant.

\section{RESULTS}

Among the bee species sampled, 11 belong to Centris Fabricius, 1804 genus, and four to Epicharis Klug, 1807 genus, while the pollen sources belong to nine botanical families and 26 pollen types (Table I and Figure 1). Based on the anther type, $80.77 \%(n=21)$ of pollen types used by bees presented non-poricidal anthers [Malpighiaceae $=19.23 \% \quad(n=5)$ and $\mathrm{NMNP}=61.54 \%(n=16)]$, and $19.23 \%(n=5)$ of them presented poricidal anthers. Only Epicharis (Epicharoides ) albofasciata Smith, 1874 did not use any poricidal sources (Table I).

The analyses showed that for all bee species, a few pollen types comprised most of the pollen grains used by the females. According to the pollen abundance, the Malpighiaceae family was the main pollen source used by almost all bee species, except for Centris (Centris) nitens Lepeletier, 1841, which used similarly the Malpighiaceae species $(44.91 \%)$ and the Solanum spp. (54.50\%).

The use of $M$. emarginata varied among the bee species. Centris (Centris) varia (Erichson, 1849) was the only species for which this pollen type was more representative than the native species of Malpighiaceae (Figure 2). Other pollen sources besides Malpighiaceae, with or without poricidal anthers, were also notably important (>30 \%) for Centris (Trachina) longimana Fabricius, 1804, Centris (Centris) flavifrons (Fabricius, 1775), Centris (Aphemisia) mocsaryi Friese, 1899, and Epicharis (Hoplepicharis) affinis Smith, 1874 (Table I).

The pollen types used by the largest number of bee species were Heteropterys type ( $n=14$ species), Solanum lycocarpum ( $n=13$ species), Byrsonima type $(n=12$ species $)$, and M. emarginata ( $n=12$ species) (Table I). The number of pollen types used by the bee species ranged from three [E. albofasciata and C. mocsaryi] to nine [C. varia and C. flavifrons] (Table II). The niche breadth presented by bees ranged from $H^{\prime}=0.55$ (E. albofasciata) to $H^{\prime}=1.95$ (C. flavifrons) (Table II).

The extrapolation analyses showed that the sampling effort ranged from 57.66 to $100.00 \%$ of the pollen types expected (Table II). The 


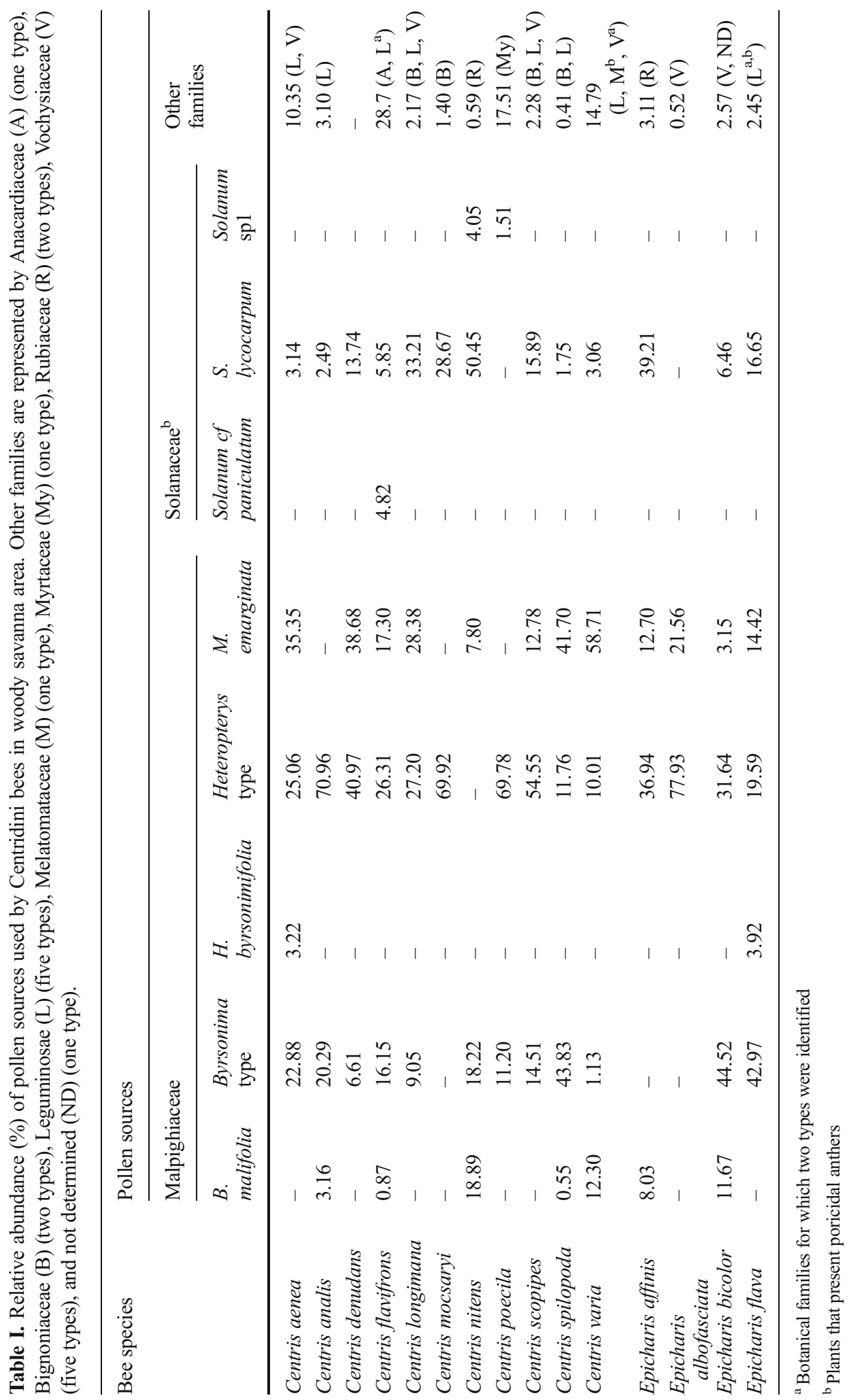




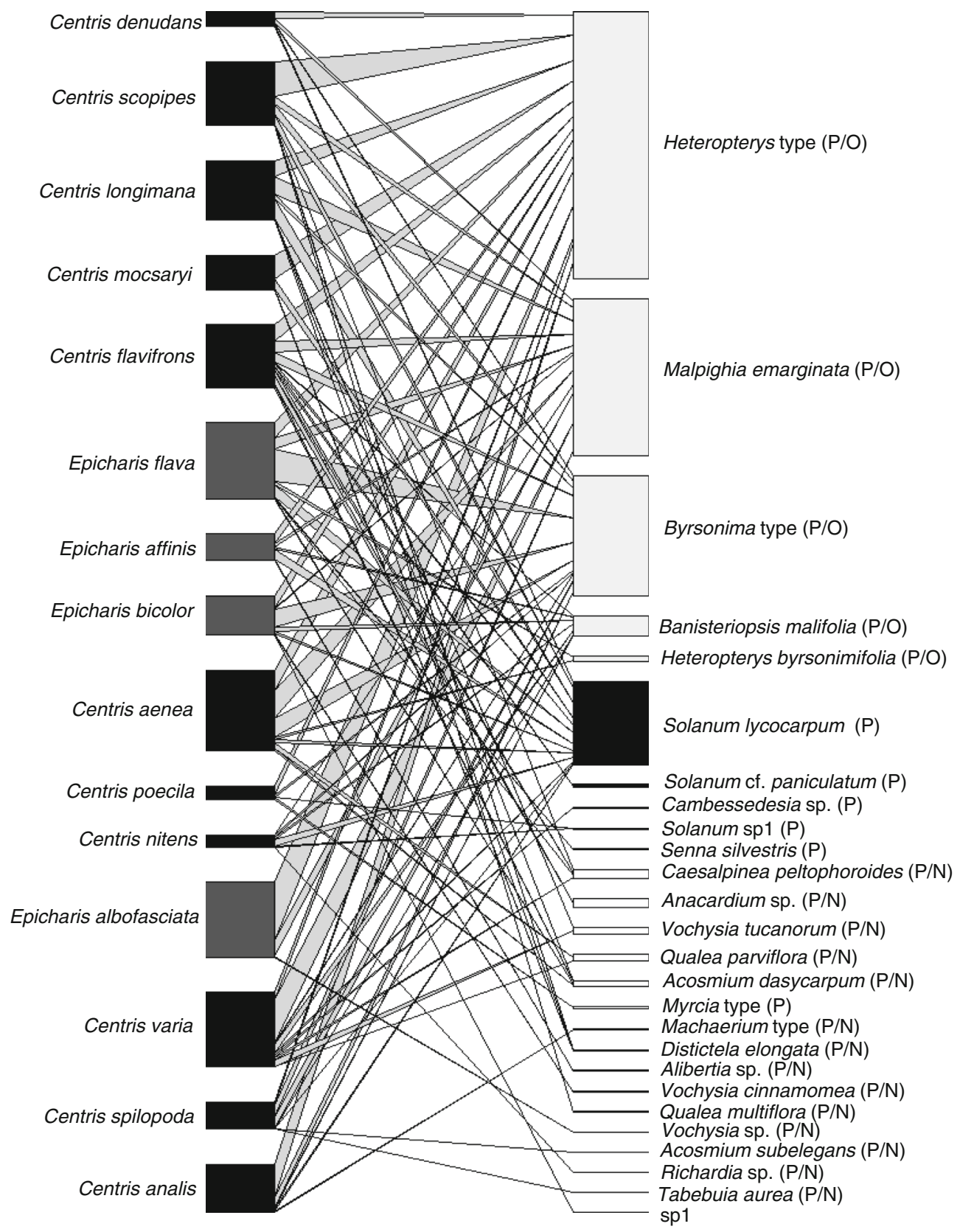

Figure 1. Interaction network between oil-collecting bees and their pollen sources. The bee species are located in the left column, and the colors represent the genus (Black: Centris; gray: Epicharis). The pollen sources are shown in the right column, and the different colors represent the anther type of pollen sources (Malpighiaceae: light gray; non-Malpighiaceae/non-poricidal: black; and poricidal: white). The thickness of the lines and the length of the rectangle are proportional to the number of pollen grains sampled. The flower resources are between parentheses, $P$ pollen, $O$ oil, and $N$ nectar, and were determined according to literature.

number of samples did not influence either the niche breadth $\left(r_{\mathrm{s}}=0.34 ; n=15 ; P>0.05\right)$ or the percentage of the expected number of pollen types sampled $\left(r_{\mathrm{s}}=0.27 ; n=15 ; P>0.05\right)$. 


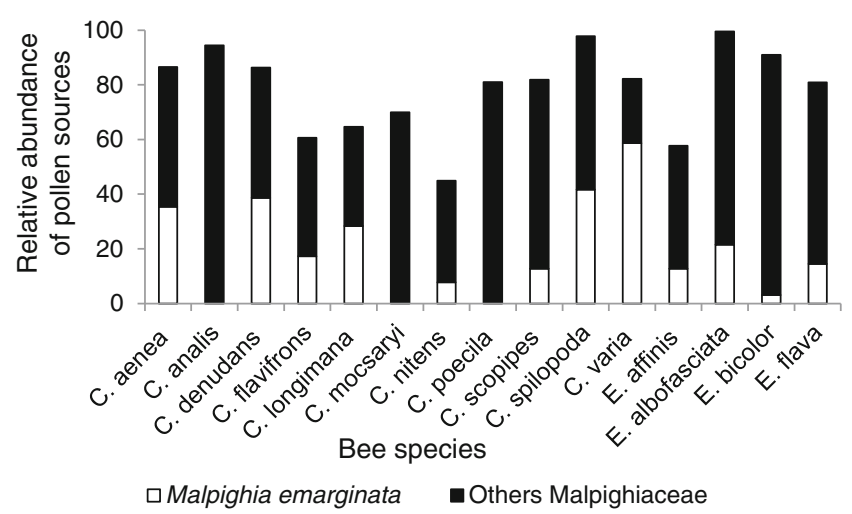

Figure 2. Relative abundance of pollen grains of Malpighia emarginata and other Malpighiaceae species for each Centridini bee species.

The smallest species was Centris (Heterocentris) analis (Fabricius, 1804), whose intertegular span was $3.14 \pm 0.08 \mathrm{~mm}$ and the largest species was Centris (Ptilotopus) denudans Lepeletier, 1841 with $8.86 \pm 0.11 \mathrm{~mm}$ (Table II).

The Non-metric Multidimensional Scale analysis showed that the bee species studied were assembled into three groups, according to proportion of
Malpighiaceae, NMNP, or poricidal sources used by each species (stress=0.01) (Figure 3). The first group, composed of $C$. flavifrons and Centris (Centris ) poecila Lepeletier, 1841, was associated with the NMNP pollen sources. The second group, consisted of Centris (Centris) aenea Lepeletier, 1841, C. analis, C. denudans, Centris (Ptilotopus) scopipes Friese, 1899, Centris

Table II. Body size of the Centridini bees based on the mean intertegular span (IS) of four specimens of each species, number of pollen load samples obtained (Samples), number of pollen types sampled (Richness), niche breadth $\left(H^{\prime}\right)$, and the number of the richness estimated by the extrapolation analysis.

\begin{tabular}{|c|c|c|c|c|c|}
\hline \multirow[t]{2}{*}{ Bee species (Codes) } & \multicolumn{5}{|l|}{ Parameters } \\
\hline & $\mathrm{IS} \pm \mathrm{SD}$ & Samples & Richness & $\left(H^{\prime}\right)$ & Extrapolation \pm SD $(\%)$ \\
\hline Centris analis (CAN) & $3.14 \pm 0.08$ & 5 & 5 & 0.88 & $5.56 \pm 1.11(89.93 \%)$ \\
\hline Centris spilopoda (CSP) & $4.70 \pm 0.15$ & 6 & 7 & 1.10 & $8.29 \pm 1.87(84.44 \%)$ \\
\hline Centris varia $(\mathrm{CV})$ & $4.84 \pm 0.48$ & 8 & 9 & 1.40 & $9.47 \pm 1.05(95.04 \%)$ \\
\hline Epicharis albofasciata (EAL) & $4.96 \pm 0.10$ & 7 & 3 & 0.55 & $3.00 \pm 0.00(100.00 \%)$ \\
\hline Centris nitens $(\mathrm{CN})$ & $4.98 \pm 0.03$ & 3 & 6 & 1.33 & $6.97 \pm 1.50(86.08 \%)$ \\
\hline Centris poecila $(\mathrm{CP})$ & $5.21 \pm 0.10$ & 2 & 4 & 0.86 & $6.15 \pm 2.91(65.04 \%)$ \\
\hline Centris aenea (CA) & $5.35 \pm 0.10$ & 6 & 7 & 1.56 & $9.53 \pm 3.08(73.45 \%)$ \\
\hline Epicharis bicolor (EB) & $5.36 \pm 0.07$ & 4 & 7 & 1.37 & $9.05 \pm 2.40(77.35 \%)$ \\
\hline Epicharis affinis (EA) & $5.94 \pm 0.35$ & 2 & 5 & 1.31 & $8.65 \pm 4.11(57.80 \%)$ \\
\hline Epicharis flava (EF) & $7.13 \pm 0.04$ & 6 & 8 & 1.50 & $10.64 \pm 2.85(75.19 \%)$ \\
\hline Centris flavifrons (CF) & $7.32 \pm 0.21$ & 6 & 9 & 1.95 & $15.61 \pm 5.18(57.66 \%)$ \\
\hline Centris mocsaryi (CM) & $7.53 \pm 0.05$ & 3 & 3 & 0.67 & $3.32 \pm 0.87(90.36 \%)$ \\
\hline Centris longimana (CL) & $7.75 \pm 0.11$ & 7 & 7 & 1.40 & $8.38 \pm 1.94(83.53 \%)$ \\
\hline Centris scopipes (CSC) & $8.78 \pm 0.17$ & 6 & 7 & 1.28 & $8.15 \pm 1.69(85.89 \%)$ \\
\hline Centris denudans (CD) & $8.86 \pm 0.11$ & 2 & 4 & 1.19 & $4.50 \pm 1.00(88.89 \%)$ \\
\hline
\end{tabular}




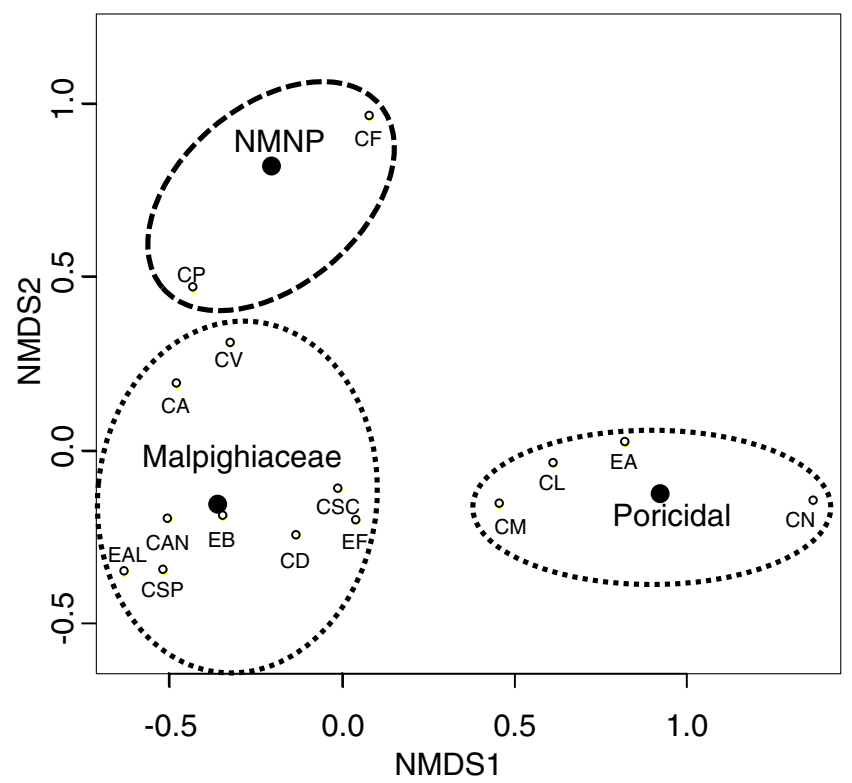

Figure 3. The ordination of the Centridini bee species in a multidimensional space according to the Non-metric Multidimensional Scale analysis based on anther type of pollen sources (NMNP non-Malpighiaceae/non-poricidal). The species codes are presented in Table II.

(Centris ) spilopoda Moure, 1969, C. varia, E. albofasciata, Epicharis (Epicharis) bicolor Smith, 1854, and Epicharis (Epicharana) flava Friese, 1900, whose main sources of pollen were Malpighiaceae. The third group, whose representatives were C. longimana, C. mocsaryi, C. nitens,

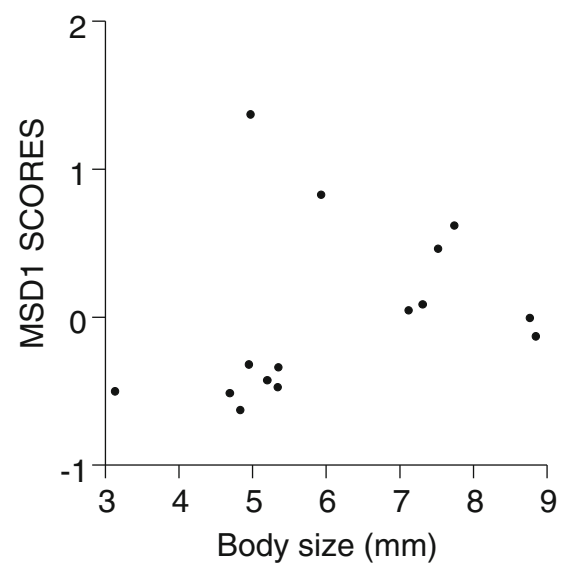

Figure 4. Influence of body size in the ordination of the Centridini bee species in the multidimensional space evaluated by the Spearman test. and E. affinis, used great amount of sources with poricidal anthers compared to others Centridini species.

Additionally, there was a significant correlation between the intertegular span of all bee species and the scores generated in NMDS for the first axis $\left(r_{\mathrm{s}}=0.589 ; P<0.05 ; n=15\right)$. This result showed that the body size is an important factor in determining the groups. The largest bees used a higher proportion of flowers with poricidal anthers compared to the smallest ones (Figures 3 and 4).

The robustness analyses showed that the systematic removal of the plant species according their anther type (Malpighiaceae, poricidal, and NMNP) reduced $19.91 \%$ of the structure resilience, given that in this case the network presented a smaller robustness index $(0.676)$ than random removal $(0.844)$. However, the removal of bee species from the largest to the smallest had no effect on the resilience of the structure, since the robustness' index (0.680) was similar to that observed from random removal (0.652). All robustness values were significantly different from the observed for null models ( $P<0.001$; Table III). 
According to the niche overlap analysis, the bee species shared more pollen types $(0.60)$ than the plants shared bee species $(0.11)$.

Although M. emarginata presents greater density compared to the plant native species, the removal of this species from the system did not cause significant changes in the observed values of robustness (Table III) and niche overlap among bees $(0.62)$ and plants $(0.09)$.

\section{DISCUSSION}

Although there was an identification of a large number of pollen types used as pollen sources by Centridini bees in our study only a few pollen types were quantitatively important for each bee species, as also observed for other species of Centris (Quiróz-Garcia et al. 2001; QuirozGarcia and Arreguin-Sánchez 2006; Dórea et al. 2010, 2013; Rabelo et al. 2012, 2014; Santos et al. 2013).

The sources of resources used by the greatest number of bee species studied herein are the families Malpighiaceae and Solanaceae, which offer pollen/oil and pollen, respectively, as floral rewards (Anderson 1979; Buchmann 1983). The oilcollecting bees gathered resources in both native (Banisteriopsis, Byrsonima, and Heteropterys) and exotic species ( $M$. emarginata), probably because of the similarity in floral morphology among Malpighiaceae species, regardless of the petal's colors, which may be yellow, pink, or white (Anderson 1979).
The West Indian Cherry is an introduced species in Brazil (Cardoso et al. 2003) and a welladapted cultivar used as source of both pollen and oil by ground-nesting and cavity-nesting oil-bee species (Vilhena and Augusto 2007; Oliveira and Schilindwein 2009; Santos et al. 2013).

Species of Solanum were also reported as important pollen sources for other Centridini bees, such as Centris (Hemisiella) trigonoides Lepeletier, 1841 (Quiróz-Garcia et al. 2001; Dórea et al. 2013), C. analis (Quiróz-Garcia et al. 2001; Rabelo et al. 2012; Santos et al. 2013), and Centris (Hemisiella) tarsata Smith, 1874 (Dórea et al. 2010; Gonçalves et al. 2012; Rabelo et al. 2014). This genus is an important pollen source for oilcollecting bees due their capacity to remove pollen using vibration (Buchmann 1983). Other pollen sources with poricidal anthers as Senna and Cambessedesia species were also registered as important pollen sources for Centridini species (Fracasso and Sazima 2004; Dórea et al. 2010; Gonçalves et al. 2012).

The formation of three groups composed of different numbers of bee species ordered by body size and another type was observed. The groups formed suggest that Centridini bees present three strategies for the use of provision sources: (1) collection of pollen mainly in Malpighiaceae species (relative abundance of pollen $>80 \%$; Table I); (2) collection of pollen from Malpighiaceae and plants with poricidal anthers; or (3) collection of pollen from Malpighiaceae and the exploitation of pollen from other non-poricidal flowers. The first strategy is probably the most basal in this group of bees. This

Table III. Robustness $(R)$ of interaction networks according to systematic removal of bee species in descending order of body size and plants based on the anther type and random removal. The results were compared with null models using one-sample $t$ tests $(d f=999)$.

\begin{tabular}{|c|c|c|c|c|}
\hline & \multicolumn{2}{|c|}{ With M. emarginata } & \multicolumn{2}{|c|}{ Without $M$. emarginata } \\
\hline & $R$ & $t$ & $R$ & $t$ \\
\hline Systematic removal of bees (body size) & 0.680 & $7,551.690^{*}$ & 0.671 & $7,395.557^{*}$ \\
\hline Radom removal of bees & 0.652 & $8,253.667 *$ & 0.633 & $8,303.912 *$ \\
\hline Systematic removal of plants (anther type) & 0.676 & $4,379.139^{*}$ & 0.663 & $4,364.779 *$ \\
\hline Radom removal of plants & 0.844 & $1,694.099^{*}$ & 0.870 & $1,207.006^{*}$ \\
\hline
\end{tabular}


idea can be supported by the fact that Centris and Epicharis are as old as the Malpighiaceae family whose diversification was fundamental for the oil-foraging behavior development, as discussed by Neff and Simpson (1981) and Renner and Schaefer (2010). Therefore, this fist strategy was the most frequently observed among the species of Centridini sampled. Pollen of Malpighiaceae composed more than $80 \%$ of the pollen grains observed for ten bee species. Epicharis albofasciata, e.g., probably used exclusively Malpighiaceae as pollen sources (99.48 \%). This species is considered a univoltine species with its activity restricted to the hot and wet season (Gaglinone 2003, 2005). Information about its food niche is scarce, but there are records of this bee species visiting only Byrsonima intermedia A. Juss. (Gaglinone 2003; Andena et al. 2012).

Although all Centridini bees are able to shake pollen out of poricidal anthers regardless of their body size, larger bees used more sources with poricidal anthers. In this context, the use of the poricidal anther could be favored by the economy of energy in the exploitation of poricidal sources and be considered as a mechanism to reduce the competition for exploitation among the species of the same guild (Burkart et al. 2011).

Only the anther type caused some effect on the resilience of the network. This result may be associated with the lower niche overlap among plants species, i.e., almost $50 \%$ of the pollen types were visited by only one bee species. On the other hand, the absence of the effect of bee body size on the resilience of the network could be a result of functional redundancy among the bee species. All of them present similar structures that allow them to collect oil (Neff and Simpson 1981; Alves-dos-Santos et al. 2007) and are able to vibrate the body (Thorp 2000), despite the differentiation in the proportion of the use of this behavior to collect pollen. Therefore, as regards the anther type, the niche overlap was more related to the plant characteristic.

In conclusion, our results supported the hypotheses proposed considering that this study showed that the parameters analyzed influenced both the use of resources by oil-collecting bees and their food niche breadth. We verified that body size of bees and anther type seems to influence the formation of subgroups in the community of Centridini bees and their pollen sources, the bee species shared more pollen types as sources of resources than the plants shared bee species as flower's visitors and that the anther type influenced the network robustness.

\section{ACKNOWLEDGMENTS}

The authors are grateful to Dr. Paulo Eugenio Oliveira (LAMOVI-IB/UFU) for the conditions offered by the laboratory, access to reference slide collections of study areas, and suggestions, to the anonymous reviewers in improving the manuscript, to all employees of Experimental Station of Água Limpa for the conditions offered to the sampling of bees, and to Coordenadoria de Aperfeiçoamento de Pessoal de Nível Superior (CAPES-PROCAD) and Fundação de Amparo à Pesquisa do Estado de Minas Gerais (FAPEMIG) for funding this study. S.C. Augusto and C.M.L. Aguiar received research fellowships from Conselho Nacional de Desenvolvimento Científico e Tecnológico (CNPq) (307222/2012-8; 306403/2012-9), and L. S. Rabelo received a grant from Coordenadoria de Aperfeiçoamento de Pessoal de Nível Superior (CAPES).

Réseau d'interactions fleurs-abeilles récolteuses d'huile: la taille de l'abeille et le type d'anthère ont-ils une influence sur l'utilisation des sources de pollen?

analyse pollinique / robustesse / service écosystémique / abeille solitaire / niche trophique

Ein Bienen-Blüten-Interaktions-Netzwerk für ölsammelnde Bienen: Haben die Grösse der Bienen und der Antheren-Typ einen Einfluss auf die Pollenquelle?

Pollenanalyse / Robustheit / Ökosystemservice / solitäre Bienen / trophische Nische

\section{REFERENCES}

Aguiar, C.M.L., Santos, G.M.M., Martins, C.F.M., Presley, S.J. (2013) Trophic niche breadth and niche overlap in a guild of flower-visiting bees in a Brazilian dry forest. Apidologie 44, 153-162 
Alves-Dos-Santos, I., Machado, I.C., Gaglianone, M.C. (2007) História natural das abelhas coletoras de óleo. Oecol. Bras. 11, 544-557

Andena, S.R., Bego, L.R., Mechi, M.R. (2005) A comunidade de abelhas (Hymenoptera, Apoidea) de uma área de cerrado (Corumbataí, SP) e suas visitas às flores. Rev. Bras. Zoociências Juiz de Fora 7, 47-54

Andena, S.R., Santos, E.F., Noll, F.B. (2012) Taxonomic diversity, niche width and similarity in the use of plant resources by bees (Hymenoptera: Anthophila) in a cerrado area. J. Nat. Hist. 46, 1663-1687

Anderson, W.R. (1979) Floral Conservatism in Neotropical Malpighiaceae. Biotropica 11, 219-223

Bastos, E.M.A.F., Thiago, P.S.S., Santana, R.M., Travassos, A. [CD-ROM] (2008) Banco de imagens de grãos de pólen: mais de 130 espécies de plantas apícolas

Begon, M., Townsend, C.R., Harper, J.L. (2006) Ecology: from individuals to ecosystems, 4th edn. Blackwell publishing, Malden

Bosch, J., Gonzaléz, A.M.M., Rodrigo, A., Navarro, D. (2009) Plant-pollinator networks: adding the pollinators perspective. Ecol. Lett. 12, 409-419

Buchmann, S.L. (1978) A biophysical model for buzz pollination in Angiosperms. J. Theor. Biol. 72, 639-657

Buchmann, S.L. (1983) Buzz pollination in Angiosperms. In: Jones, C.E., Little, R.J. (eds.) Handbook of experimental pollination biology, pp. 73-113. Van Nostrand and Reinhold, New York

Burkart, A., Lunau, K., Schlindwein, C. (2011) Comparative bioacoustical studies on flight and buzzing of neotropical bees. J. Poll. Ecol. 6, 118-124

Camillo, E., Garófalo, C.A. (1989) Analysis of the niche of two sympatric species of Bombus (Hymenoptera, Apidae) in southeastern Brazil. J. Trop. Ecol. 5, 81-92

Cane, J.H. (1987) Estimation of bee size using intertegular span (Apoidea). J. Kansas Entomol. Soc. 60, 145-147

Cardoso, C.E.L., Lopes, R.L., Almeida, C.O. (2003) Aspectos Econômicos. In: Ritzinger, R., Kobayashi, A.K., Oliveira, J.R.P. (eds.) A cultura da aceroleira. Embrapa Mandioca e Fruticultura, pp. 185-198. Cruz das Almas, Brazil

Carvalho, D.A., Oliveira, P.E. (2003) Biologia reprodutiva e polinização de Senna sylvestris (Vell.) H.S. Irwin and Barneby (Leguminosae, Caesalpinioideae). Rev. Bras. Bot. 26, 319-328

Carvalho, D.M., Aguiar, C.M.L., Santos, G.M.M. (2013) Food niche overlap among neotropical carpenter bees (Hymenoptera: Apidae: Xylocopini) in an agricultural system. Sociobiology 60, 283-288

Colwell, R.K. (2013) EstimateS: Statistical estimation of species richness and shared species from samples, version 9. URL < http://purl.oclc.org/estimates>

Cortopassi-Laurino, M., Knoll, F.R.N., Imperatriz-Fonseca, V.L. (2003) Nicho trófico e abundância de Bombus morio e Bombus atratus em diferentes biomas brasileiros. In: Melo, G.A.R., Alves-dos-Santos, I.C. (eds.) Homenagem aos 90 anos de Jesus Santiago Moure, Apoidea Neotropica, pp. 285-295. UNESC, Criciúma
Del Lama, M.A., Peruquetti, R.C. (2006) Mortalidade de abelhas visitantes de flores de Caesalpinia peltophoroides Benth (Leguminosae) no estado de São Paulo, Brasil Rev. Bras. Entomol. 50, 547-549

Dórea, M.C., Aguiar, C.M.L., Figueroa, L.E.R., Lima, L.C.L., Santos, F.A.R. (2010) Pollen residues in nests of Centris tarsata Smith (Hymenoptera, Apidae, Centridini) in a tropical semi-arid area in NE Brazil. Apidologie 41, 557-567

Dórea, M.C., Aguiar, C.M.L., Figuero, L.E.R., Lima, L.C.L., Santos, F.A.R. (2013) A study of pollen residues in nests of Centris trigonoides Lepeletier (Hymenoptera, Apidae, Centridini) in the Caatinga vegetation, Bahia, Brazil. Grana 52, 122-128

Dormann, C.F., Gruber, B. (2012) Package "bipartite": Visualising bipartite networks and calculating some (ecological) indices

Dunne, J.A., Williams, R.J., Martinez, N.D. (2002) Network structure and biodiversity loss in food webs: robustness increases with connectance. Ecol. Lett. 5, 558-567

Erdtman, G. (1960) The acetolized method. A revised description. Sven. Bot. Tidskr. 54, 561-564

Evans, D.M., Pocock, M.J.O., Memmott, J. (2013) The robustness of a network of ecological networks to habitat loss. Ecol. Lett. 16, 844-852

Filho, C.V.M., Tozzi, A.M.G.A., Martins, E.R.F. (2007) Revisão taxonômica de Machaerium Sect. Oblonga (Benth.) Taub. (Leguminosae, Papilionoideae, Dalbergieae). Rodriguésia 58, 283-312

Fracasso, C.M., Sazima, M. (2004) Polinização de Cambessedesia hilariana (Kunth) DC. (Melastomataceae): sucesso reprodutivo versus diversidade, comportamento e freqüência de visitas de abelhas. Rev. Bras. Bot. 27, 797-804

Frankie, G.W., Haber, W.A., Opler, P.A., Bawa, K.S. (1983) Characteristics and organization of the large bee pollination system in the Costa Rican dry forest. In: Jones, C.E., Little, R.J. (eds.) Handbook of Experimental Pollination Biology, pp. 411-447. Van Nostrand Reinhold Co, Nova York

Freitas, B.M., Paxton, R.J. (1998) A comparison of two pollinators: the introduced honey bee Apis mellifera and an indigenous bee Centris tarsata on cashew Anacardium occidentale in its native range of $\mathrm{NE}$ Brazil. J. Appl. Ecol. 35, 109-121

Freitas, B.M., Alves, J.E., Brandão, G.F., Araújo, Z.B. (1999) Pollination requirements of West Indian cherry (Malpighia emarginata) and its putative pollinators, Centris bees, in NE Brazil. J. Agric. Sci. 133, 303-311

Gaglinone, M.C. (2003) Abelhas da tribo Centridini na Estação Ecológica de Jatai (Luiz Antônio, SP): composição de espécies e interações com flores de Malpighiaceae. In: Melo, G.A.R., Alves-dos-Santos, I. (eds.) Apoidea Neotropical: Homenagem aos 90 anos de Jesus Santiago Moure, pp. 279-284. UNESC, Criciúma

Gaglinone, M.C. (2005) Nesting biology, seasonality, and flower hosts of Epicharis nigrita (Friese, 1900) (Hymenoptera: Apidae: Centridini), with a comparative 
analysis for the genus. Stud. Neotropical Fauna Environ. $40,191-200$

Gonçalves, L., Silva, C.I., Buschini, M.L.T. (2012) Collection of pollen grains by Centris (Hemisiella) tarsata Smith (Apidae: Centridini): is C. tarsata an oligolectic or polylectic species? Zool. Stud. 51, 195-203

Goulson, D., Darvill, B. (2004) Niche overlap and diet breadth in bumblebees; are rare species more specialized in their choice of flowers? Apidologie 35, 55-63

Greenleaf, S.S., Williams, N.M., Winfree, R., Kremen, C. (2007) Bee foraging ranges and their relationship to body size. Oecologia 153, 589-596

Harder, L.D., Barclay, R.M.R. (1994) The functional significance of poricidal anthers and buzz pollination: controlled pollen removal from Dodecatheon. Funct. Ecol. 8, 509-517

Jones, G.D., Jones, S.D. (2001) The uses of pollen and its implication for entomology. Neotrop. Entomol. 30, 314-349

Jordano, P., Bascompte, J., Olesen, J.M. (2003) Invariant properties in coevolutionary networks of plant-animal interactions. Ecol. Lett. 6, 69-81

Kill, L.H.P., Haji, F.N.P., Lima, P.C.F. (2000) Visitantes florais de plantas invasoras de áreas com fruteiras irrigadas. Sci. Agric. 57, 575-580

Lewinsohn, T.M., Prado, P.I., Jordano, P., Bascompte, J., Olesen, J.M. (2006) Structure in plant-animal interaction assemblages. Oikos 113, 174-184

Memmott, J., Waser, N.M., Price, M.V. (2004) Tolerance of pollination networks to species extinctions. Proc. Biol. Sci. 271, 2605-2611

Neff, J.L., Simpson, B.B. (1981) Oil-Collecting structures in the Anthophoridae (Hymenoptera): morphology, function, and use in systematics. J. Kansas Entomol. Soc. 54, 95-123

Neto, P.L. (2008) Levantamento planimétrico $n^{\circ} 36.243$, prefeitura de Uberlândia, Minas Gerais

Nogueira-Ferreira, F.H., Augusto, S.C. (2007) Amplitude de nicho e similaridade no uso de recursos florais por abelhas eussociais em uma área de Cerrado. Biosci. J. 23, 45-51

Oliveira, P., Gibbs, P. (1994) Pollination biology and breeding systems of six Vochysia species (Vochysiaceae) in Central Brazil. J. Trop. Ecol. 10, 509-522

Oliveira, P.S., Silva, A.F., Martins, A.B. (1987) Ant foraging on extrafloral nectarines of Qualea granditlora (Vochysiaceae) in cerrado vegetation: ants as potential antiherbivore agents. Oecologia (Berlin) 74, 228-230

Oliveira, R., Schilindwein, C. (2009) Searching for a manageable pollinator for West Indian cherry orchards: the solitary oil collecting bee Centris analis (Hymenoptera: Apidae: Centridini). J. Econ. Entomol. 102, 20273

Oliveira, G.A., Aguiar, C.M.L., Silva, M., Gimenes, M. (2013) Centris aenea (Hymenoptera, Apidae): a ground-nesting bee with high pollination efficiency in
Malpighia emarginata DC (Malpighiaceae). Sociobiology 60, 317-322

Pereira, M.S., Barbosa, M.R.V. (2004) A família Rubiaceae na Reserva Biológica Guaribas, Paraíba, Brasil. Subfamílias Antirheoideae, Cinchonoideae e Ixoroideae. Acta Bot. Bras. 18, 305-318

Pool, A. (2009) A review of the genus Distictella (Bignoniaceae). Ann. Mo. Bot. Gard. 96, 286-323

Quinn, G.P., Keough, M.J. (2002) Experimental design and data analysis for biologists. CUP, UK

Quiroz-Garcia, D.L., Arreguin-Sánchez, M.L. (2006) Resource utilization by Centris flavofasciata Friese (Hymenoptera: Apidae) in Jalisco, Mexico. J. Kansas Entomol. Soc. 79, 249-253

Quiróz-Garcia, D.L., Martinez-Hernandez, E., PalaciosChavez, R., Galindo-Miranda, N.E. (2001) Nest provisions and pollen foraging in three species of solitary bees (Hymenoptera: Apidae) from Jalisco, Mexico. J. Kansas Entomol. Soc. 74, 61-69

Rabelo, L.S., Vilhena, A.M.G.F., Bastos, E.M.A.F., Augusto, S.C. (2012) Larval food sources of Centris (Heterocentris) analis (Fabricius, 1804) (Hymenoptera: Apidae), an oil-collecting bee. J. Nat. Hist. 46, 1129-1140

Rabelo, L.S., Vilhena, A.M.G.F., Bastos, E.M.A.F., Augusto, S.C. (2014) Differentiated use of pollen sources by two sympatric species of oil-collecting bees (Hymenoptera: Apidae). J. Nat. Hist. . doi:10.1080/ 00222933.2014 .886342

Ragusa-Netto, J. (2005) Extensive consumption of Tabebuia aurea (Manso) Benth. and Hook. (Bignoniaceae) nectar by parrots in a tecoma savanna in the southern Pantanal (Brazil). Braz. J. Biol. 65, 339-344

Renner, S.S., Schaefer, H. (2010) The evolution and loss of oil-offering flowers: new insights from dated phylogenies for angiosperms and bees. Phil. Trans. R. Soc. B 365, 423-435

Ribeiro, E.K.M.D., Rêgo, M.M.C., Machado, I.C.S. (2008) Cargas polínicas de abelhas polinizadoras de Byrsonima chrysophylla Kunth (Malpighiaceae): fidelidade e fontes alternativas de recursos florais. Acta Bot. Bras. 22, 165-171

Rosa, R., Lima, S.C., Assunção, W.L. (1991) Abordagem preliminar das condições climáticas de Uberlândia. Soc. Naturezal. 5, 98-101

Roubik, D.W., Moreno, J.E. (1991) The pollen and spores of Barro Colorado Island. Missouri Botanical Garden, St Louis (Missouri)

Salgado-Labouriau, M.L. (1973) Contribuição à palinologia dos Cerrados. Academia Brasileira de Ciências, Brazil

Santos, R.M., Aguiar, C.M.L., Dórea, M.C., Almeida, G.F., Santos, F.A.R., Augusto, S.C. (2013a) The larval provisions of the crop pollinator Centris analis: pollen spectrum and trophic niche bread thin an agroecosystem. Apidologie 44, 630-641

Santos, G.M.M., Carvalho, C.A.L., Aguiar, C.M.L., Macêdo, L.S.S.R., Mello, M.A.R. (2013b) Overlap in 
trophic and temporal niches in the flower-visiting bee guild (Hymenoptera, Apoidea) of a tropical dry forest. Apidologie 44, 64-74

Souza, V.C., Lorenzi, H. (2005) Botânica sistemática: guia ilustrado para identificação das famílias de Angiospermas da flora brasileira, baseado em APG II, Imprenta Nova Odessa, Instituto Plantarum de Estudos da Flora

Staniczenko, P.P.A., Lewis, O.T., Jones, N.S., ReedTsochas, F. (2010) Structural dynamics and robustness of food webs. Ecol. Lett. 13, 891-899

Thorp, R.W. (2000) The collection of pollen by bees. Plant Syst. Evol. 222 , 211-223

Vilhena, A.M.G.F., Augusto, S.C. (2007) Polinizadores da aceroleira Malpighia emarginata DC (Malpighiaceae) em área de cerrado no Triângulo Mineiro. Biosci. J. 23, 14-23

Vilhena, A.M.G.F., Rabelo, L.S., Bastos, E.M.A.F., Augusto, S.C. (2012) Acerola pollinators in the savanna of Central Brazil: temporal variations in oilcollecting bee richness and a mutualistic network. Apidologie 43, 51-62

Yamamoto, M., Silva, C.I., Augusto, S.C., Barbosa, A.A.A., Oliveira, P.E. (2012) The role of bee diversity in pollination and fruit set of yellow passion fruit (Passiflora edulis forma flavicarpa, Passifloraceae) crop in Central Brazil. Apidologie 43, 515-526

Zar, J.H. (2010) Biostatistical analysis. 5th ed. Imprenta Upper Saddle River, Prentice Hall 